\title{
Relevansi Putusan Uji Materi oleh Mahkamah Konstitusi terhadap Sistem Checks and Balances dalam Pembentukan Undang-Undang
}

\author{
Despan Heryansyah ${ }^{\star}$, Harry Setya Nugraha ${ }^{\star \star}$ \\ ^ Program Doktor Ilmu Hukum Universitas Islam Indonesia \\ despan.her@gmail.com

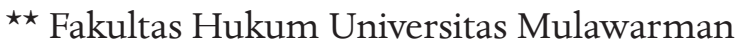 \\ harrysetyanugraha@fh.unmul.ac.id
}

\begin{abstract}
This article discusses the relevance of the judicial review decision by the Constitutional Court to the checks and balances system in law legislation in Indonesia. In the framework of checks and balances between state institutions, the existence of the authority of the Constitutional Court to examine laws against the Constitution can be seen as a limitation for the legislators. This is because the discretion of legislators, namely the President and the House of Representatives, in carrying out the legislation function can be limited by the interpretation of the Constitution carried out by the Constitutional Court. This article concludes, the checks and balances mechanism regulated in the 1945 Constitution of the Republic of Indonesia is realized with the principle of power limited by power. Therefore, the authority and decision of the judicial review by the Constitutional Court is not an intervention on the authority of lawmakers so that it isi assumed to pass the checks and belances principle. The authority and decision of the judicial review by the Constitutional Court actually confirms the manifestation of the principle of power limited by power and affirming the supremacy of the Constitution. Thus, the principle of supremacy of the Constitution in the context of the rule of law places the Constitution as the highest law.
\end{abstract}

Keywords: supremacy of the Constitution; law legislation; judicial review; checks and balances. 


\section{Abstrak}

Artikel ini membahas relevansi putusan uji materi oleh Mahkamah Konstitusi terhadap sistem checks and balances dalam pembentukan hukum berupa undang-undang di Indonesia. Dalam kerangka checks and balances antar lembaga negara, adanya kewenangan Mahkamah Konstitusi menguji undang-undang terhadap Konstitusi dapat dipandang sebagai suatu pembatasan bagi pembentuk undang-undang. Sebab, keleluasaan pembentuk undang-undang, yaitu Presiden dan Dewan Perwakilan Rakyat, dalam menjalankan fungsi legislasi bisa dibatasi oleh adanya tafsir Konstitusi yang dilakukan oleh Mahkamah Konstitusi. Artikel ini menyimpulkan, mekanisme checks and balances yang diatur dalam Undang-Undang Dasar Negara Republik Indonesia Tahun 1945 diwujudkan dengan prinsip kekuasaan dibatasi oleh kekuasaan. Karena itu, kewenangan dan putusan uji materi oleh Mahkamah Konstitusi bukanlah wujud intervensi terhadap kewenangan pembentuk undang-undang dan melampaui prinsip checks and balances. Kewenangan dan putusan uji materi oleh Mahkamah Konstitusi justru menegaskan wujud dari prinsip kekuasaan dibatasi kekuasaan dan meneguhkan supremasi Konstitusi. Demikianlah, prinsip supremasi Konstitusi dalam konteks negara hukum yang menempatkan Konstitusi sebagai hukum tertinggi.

Kata kunci: supremasi Konstitusi; pembentukan hukum; uji materi; checks and balances.

\section{A. Pendahuluan}

Artikel ini membahas relevansi putusan uji materi (judicial review) oleh Mahkamah Konstitusi terhadap sistem checks and balances dalam pembentukan hukum berupa undang-undang. Adanya kewenangan Mahkamah Konstitusi menguji konstitusionalitas suatu undangundang pada satu sisi mendorong agar setiap undang-undang yang dibuat sejalan dengan Konstitusi, namun di sisi lain juga mendobrak tradisi pembagian kekuasaan dengan sistem checks and balances, disebabkan putusan Mahkamah bisa saja membatalkan regulasi yang telah dibuat oleh Presiden dan Dewan Perwakilan Rakyat sebagai lembaga yang secara konstitusional diberikan kewenangan membentuknya. Karena alasan itu, penting untuk ditelaah lebih 
lanjut, bagaimana sebenarnya relevansi putusan uji materi oleh Mahkamah Konstitusi dikaitkan dengan sistem checks and balances dalam pembentukan undang-undang.

Prinsip checks and balances pada mulanya dimaknai sebagai prinsip dalam studi ketatanegaraan yang menghendaki agar kekuasaan legislatif, eksekutif, dan yudikatif sama-sama sederajat dan saling mengontrol satu sama lain. Kekuasaan harus dikontrol, dibatasi, dan diatur sedemikian rupa, dengan tujuan agar dapat menghindari sekecil mungkin adanya potensi penyalahgunaan kekuasaan oleh oknum peneyelenggara negara. ${ }^{1}$ Dalam konteks negara demokrasi, mekanisme checks and balances tidak saja diperlukan, namun bahkan menjadi tiang bagi tegaknya negara demokrasi itu sendiri. Ia, checks and balances, diperlukan untuk menghindari penyalahgunaan kekuasaan dan terpusatnya kekuasaan pada seseorang ataupun sebuah institusi, sehingga antar institusi akan saling mengontrol atau mengawasi, bahkan bisa saling mengisi. ${ }^{2}$ Mekanisme ini akan dapat berjalan apabila masing-masing institusi yang saling mengawasi itu memiliki power yang setara.

Di Indonesia, ketiadaan mekanisme checks and balances dianggap sebagai salah satu kelemahan dalam Undang-Undang Dasar Negara Republik Indonesia (UUD NRI) Tahun 1945 sebelum amandemen. Pada saat itu presiden menjadi pusat kekuasaan dengan berbagai hak prerogatifnya. Selain menguasai bidang eksekutif, presiden memiliki setengah dari kekuasaan legislatif yang dalam praktiknya juga menjadi ketua legislatif. UUD NRI Tahun 1945 juga tidak mengatur mekanisme uji materi (judicial review), padahal seringkali lahir produk legislasi yang dipersoalkan konsistensinya dengan Konstitusi karena lebih banyak didominasi oleh keinginan-keinginan politik dari pemerintah. ${ }^{3}$ Padahal sistem checks and balances merupakan

1 Jimly Asshiddiqie, Konstitusi dan Konstitusionalisme Indonesia (Jakarta: Sinar Grafika, 2010), hlm. 61.

2 Afan Gaffar, Politik Indonesia: Transisi Menuju Demokrasi (Yogyakarta: Pustaka Pelajar, 2006), hlm. 89.

3 Moh. Mahfud MD, Demokrasi dan Konstitusi di Indonesia: Studi tentang Interaksi Politik dan Kehidupan Ketatanegaraan (Jakarta: Rineka Cipta, 2000), hlm. 147. 
instrumen penting untuk menjaga dan mencegah tindakan sewenangwenang atau tindakan melampaui wewenang. Dengan kata lain, checks and balances adalah penjamin kelangsungan penyelengaraan negara dan pemerintahan secara demokratis, negara hukum, dan berdasarkan konstitusionalisme. ${ }^{4}$ Checks and balances adalah inti dari konstitusionalisme. ${ }^{5}$

Pada perkembangan terakhir, sistem checks and balances justru dimaknai bahwa masing-masing lembaga negara memiliki kewenangan tersendiri yang tidak boleh saling mencampuri, atau dengan istilah lain "konsepsi kekuasaan dibatasi dengan kekuasaan". Kekuasaan yang dimiliki oleh presiden dibatasi oleh kekuasaan yang dimiliki oleh DPR. ${ }^{6}$ Bagitu pula dengan kewenangan DPR dan Presiden dalam membentuk undang-undang, dibatasi oleh kewenangan Mahkamah Konstitusi untuk menguji kesesuaiannya dengan Konstitusi. ${ }^{7}$

Kewenangan Mahkamah Konstitusi untuk melakukan pengujian (judicial review) undang-undang terhadap Konstitusi merupakan konstruksi baru yang sebelumnya tidak dikenal dan

4 Bagir Manan, Membedah UUD 1945 (Malang: Universitas Brawijaya Press, 2012), hlm. 88.

5 Jika tidak ada satu orang atau kelompok kecil orang memegang semua kekuasaan, maka tidak ada yang akan memiliki kekuatan tak terbatas untuk menindas orang lain. Ketika salah satu bagian dari pemerintah perlu kerjasama dari bagian lain dari pemerintah untuk mengamankan sesuatu yang diinginkan, maka akan dipaksa untuk mendengarkan, untuk bernegosiasi, dan bekerja sama. Ketika banyak orang yang berbeda memiliki kekuatan untuk mempengaruhi tindakan pemerintah, kemungkinan akan lebih adil, karena tidak akan melayani kepentingan hanya sekelompok kecil; dan akan lebih tercerahkan, karena akan mencerminkan proses diskusi di mana banyak perspektif dibawa untuk menanggung atas setiap pengambilan keputusan. N. Krisch, Beyond Constitutionalism (Oxford: Oxford University Press), 69-103, dikutip dari Ibnu Sina Chandranegara, "Penuangan Checks and Balances ke dalam Konstitusi”, Jurnal Konstitusi, 13, 3 (2016), hlm. 554.

6 Sebagai contoh konkret misalnya, Presiden diberikan kewenangan untuk menunjuk Pimpinan KPK, namun kewenangan ini dibatasi oleh kewenangan DPR untuk memberikan persetujuan atau tidak terhadap pimpinan yang diusulkan oleh presiden.

7 Judicial review terhadap undang-undang adalah mekanisme checks and balancesbaru yang diadopsi oleh Indonesia pasca amandemen UUD NRI Tahun 1945. 
bahkan cenderung diharamkan. ${ }^{8}$ Hal ini disebabkan masingmasing cabang kekuasaan, yaitu eksekutif, legislatif, dan yudikatif, sesungguhnya terpisah dan tidak boleh saling mencampuri. Kewenangan Mahkamah untuk melakukan uji materi ini merupakan sarana untuk menjadikan konstitusi sebagai dokumen hidup (a living document) yang menentukan bentuk dan arah kekuasaan negara sesuai dengan prinsip dasar dalam konstitusi berdasarkan demokrasi. Dengan demikian Mahkamah memberi kontribusi bagi terciptanya kehidupan bernegara berdasarkan hukum dan demokrasi. ${ }^{9}$

Kewenangan Mahkamah Konstitusi menguji kesesuaian suatu undang-undang dengan Konstitusi ini apabila dihubungkan dengan kerangka checks and balances antar lembaga negara dapat dipandang sebagai suatu pembatasan bagi pembentuk undang-undang. Sebab, keleluasaan pembentuk undang-undang (presiden dan DPR) dalam menjalankan fungsi legislasi bisa dibatasi oleh adanya tafsir Konstitusi yang dilakukan oleh Mahkamah Konstitusi. Dengan demikian, apa yang disebut konstitusional tidak lain adalah apa yang dikatakan hakim Konstitusi. Batasan tentang konstitusional merupakan konsekuensi dari pelaksanaan fungsi Mahkamah Konstitisi selaku panafsir konstitusi. Pembatasan tersebut merupakan wujud dari prinsip kekuasaan dibatasi kekuasaan (power limited by power), yang berarti kewenangan pembentuk undang-udang untuk menafsirkan dan menjabarkan Konstitusi melalui legislasi dibatasi oleh penafsiran Mahkamah melalui putusannya. Demikianlah prinsip supremasi konstitusi ${ }^{10}$ yang dapat dimaknai sebagai negara yang menempatkan Konstitusi menjadi hukum tertinggi dan Mahkamah Konstitusi diberi kewenangan konstitusional sebagai pengawalnya.

8 Meskipun sejak awal pembentukan Konstitusi Indonesia, ide mengenai judicial review pernah muncul, namun karena mendapatkan penolakan, belum dapat terlaksana.

9 I Dewa Gede Palguna, "Pengaduan Konstitusional: Upaya Hukum terhadap Pelanggaran Hak-Hak Konstitusional Warga Negara (Studi Kewenangan Mahkamah Konstitusi Indonesia dalam Perspektif Perbandingan)" (disertasi, Universitas Indonesia, Jakarta, 2011), hlm. 157.

10 Makna supremasi konstitusi, bagaimana ia dilahirkan dan apa dampaiknya dalam kehidupan berbangsa dan bernegara akan penulis paparkan lebih lanjut dalam Bab analisis kemudian. 
Berdasarkan uraian tersebut, timbul pertanyaan, apakah dengan demikian dapat dikatakan Mahkamah Konstitusi menyerobot kewenangan presiden dan DPR selaku pembentuk undang-undang, dan dengan demikian, apakah Mahkamah berarti juga telah merusak bangunan checks and balances dalam pembentukan undang-undang. Artikel ini akan mendiskusikan lebih lanjut persoalan tersebut, dengan bahasan meliputi supremasi Konstitusi, Mahkamah Konstitusi dan penafsiran Konstitusi, serta putusan Mahkamah Konstitusi dan checks and balancess. Uraian supremasi Konstitusi dimaksudkan untuk menjelaskan bahwa telah terjadi pergeseran paradigma ketatanegaraan dalam pembentukan undang-undang pasca amandemen UUD NRI 1945 pada 1999-2002, yaitu dari peneguhan supremasi parlemen menuju supremasi Konstitusi. Uraian Mahkamah Konstitusi dan penafsiran Konstitusi dimaksudkan untuk menjelaskan bahwa pengujian undang-undang oleh Mahkamah pada dasarnya adalah bagian dari upaya penafsiran Konstitusi terhadap suatu undangundang agar konstitusional. Pada bagian akhir, uraian putusan Mahkamah Konstitusi dan checks and balances, ingin menjawab pertanyaan dalam artikel ini, bahwa kewenangan uji materi oleh Mahkamah sesungguhnya tidaklah melampaui prinsip batasan checks and belances, sebab kewenangan pembentuk undang-undang untuk menafsirkan Konstitusi melalui legislasi dibatasi oleh penafsiran Konstitusi yang dilakukan Mahkamah Konstitusi melalui putusannya. Dengan demikian, putusan uji materi memiliki relevansi terhadap sistem checks and balances dalam pembentukan undang-undang.

\section{B. Dari Supremasi Parlemen Menuju Supremasi Konstitusi}

Pasca amandemenUUDNRI 1945 pada 1999-2002, terdapatperubahan paradigma sistem ketatanegaraan dari semula lebih cenderung pada peneguhan prinsip supremasi parlemen menjadi menuju supremasi Konstitusi. Jika sebelumnya mandataris kedaulatan rakyat secara mutlak dijalankan oleh Majelis Permusyawaratan Rakyat (MPR) yang terdiri atas DPR dan Utusan Golongan serta Daerah (supremasi parlemen), maka kini dengan supremasi Konstitusi, semua lembaga 
berada pada level yang sejajar dan tunduk pada sistem yang dibentuk dalam Konstitusi. Dua prinsip pokok yang diadopsi dan diperkuat dalam UUD pasca amandemen adalah, pertama, prinsip demokrasi yang berdasarkan atas hukum (constitutional democracy), dan kedua, prinsip negara hukum yang demokratis (democratic rule of law). Ini artinya, sistem demokrasi diperkuat dengan prinsip-prinsip mendasar dalam negara hukum untuk memastikan bahwa kedaulatan benarbenar seperti yang disyaratkan oleh Abraham Linclon, berasal dari rakyat diselenggarakan oleh rakyat, dan untuk kepentingan rakyat. Bersamaan dengan itu, prinsip democratic rule of law juga dipertegas. Namun demikian, yang patut disayangkan, perubahan atau pergeseran paradigma ini tidak banyak dipahami, baik pada level masyarakat maupun pemerintah (dalam arti luas). ${ }^{11}$

Supremasi parlemen atau disebut oleh Alec Stone Sweet dengan istilah legislative souvereignity merupakan old constitusionalism, sedangkan supremasi konstitusi merupakan new constitusinalism. Di Eropa, menurut Stone, pergerakan old constitusionalism menuju new constitusinalism sangat bergantung pada constititional review sebagai mekanisme pemerintahan. Dalam new constitusinalism ditemui lima ciri, pertama, lembaga negara yang dibentuk oleh, serta menurunkan otoritas mereka secara ekslusif dari konstitusi tertulis; kedua, Konstitusi memberikan kekuasaan tertinggi kepada orangorang dengan cara pemilihan; ketiga, penggunaan otoritas publik, termasuk otoritas legislatif adalah sah hanya sejauh sesuai dengan hukum konstitusi; keempat, Konstitusi memberikan hak dan sistem keadilan konstitusional untuk membela hak-hak mereka; dan kelima, pengadilan konstitusional tidak hanya memiliki kewajiban, akan tetapi sepenuhnya diberdayakan untuk mengelola sistem hukum. ${ }^{12}$

11 Gunars Kutaris, "Authority of the Constitutional Court as the Preconditions of Execution of the Decisions", makalah Konferensi "Execution of The Decisons of Constitutional Court: A Cornerstone of the Process of Implementation of Constitutional Justice" on The Occasion of the 10th Anniversary of the Constitutional Court of Azerbaijan, Baku, Azerbaijan, 14-15 Juli 2008.

12 Alec Stone Sweet, "The Politics of Constitutional Review in France and Europe”, International Journal of Constitutional Law, 5, 1 (2007), hlm. 74. 
Dalam konteks Indonesia, jika pada periode sebelum amandemen UUD dapat dikatakan undang-undang yang dibentuk oleh parlemen bersama dengan pemerintah tidak dapat diganggu-gugat, maka pasca amandemen dapat diuji materi (judicial review) oleh Mahkamah Konstitusi. Inilah makna dari perubahan supremasi parlemen menjadi supremasi Konstitusi, bahwa Konstitusi menjadi standar, acuan, pedoman, dan norma dalam penyelenggaraan kehidupan berbangsa, bernegara, dan bermasyarakat, termasuk dalam pembentukan undang-undang. Oleh karenanya, sekalipun undangundang adalah produk DPR yang terdiri atas 560 orang ditambah presiden, dapat saja dibatalkan oleh Mahkamah Konstitusi yang hanya terdiri sembilan orang hakim, karena itu merupakan amanat Konstitusi. ${ }^{13}$ Dalam rezim pemerintahan demokratis, seluruh metode uji materi memiliki tujuan utama untuk menjamin supremasi Konstitusi, dan konsekuensinya, Mahkamah memiliki tugas untuk mengonfrontasikan produk legislasi dengan ketentuan dalam UUD. Itulah mengapa uji materi bersifat fundamental dalam pemerintahan yang demokratis sebagai kontrol konstitusioal terhadap legislasi, atau

13 Kekurangpahaman perubahan paradigma ketatanegaraan dari supremasi parlemen menuju supremasi Konstitusi menumbuhkan cara pandang kurang tepat terhadap hakikat Mahkamah Konstitusi. Misalnya, pertanyaan yang masih sering muncul, mengapa Mahkamah Konstitusi yang terdiri atas sembilan hakim konstitusi dapat membatalkan produk DPR yang terdiri dari 560 orang dan presiden. Demikian juga, mengapa sebuah unsur non-elektif dapat menolak keputusan perihal konstitusionalitas norma undang-undang dari dua cabang kekuasaan yang elektif. Namun begitu, bukan berarti kritik tidak diperlukan terhadap Mahkamah Konstitusi yang memiliki kewenangan yang sangat besar itu. Satjipto Rahardjo misalnya, menyayangkan karena Mahkamah Konstitusi sebagai penafsir Konstitusi berisi mereka yang berlatar belakang hukum. Padahal, Konstitusi bukan saja menjadi landasan tatanan hukum, melainkan juga kehidupan sosial, politik, ekonomi kultural, dan lain-lain. Karena kesadaran demikian, dalam sejarah penyusunan Konstitusi, founding fathers Indonesia diisi oleh mereka dengan berbagai latar belakang. Dalam kepanitian Badan Penyelidik Usaha Persiapan Kemerdekaan (BPUPK), dari 20 orang hanya ada empat ahli hukum, sedangkan dalam "Panitia Sembilan" yang diserahi penyusunan draf terakhir, hanya ada tiga ahli hukum. Pembentukan Mahkamah Konstitusi dengan sembilan hakim mengesankan bahwa Mahkamah ini identik belaka dengan mahkamah pengadilan. Lihat Satjipto Rahardjo, "Sisi Lain Mahkamah Konstitusi”, Kompas, 5/1/2009. 
kontrol yudisial terhadap konstitusionalitas legislasi. Sebab, bukan tidak mungkin suatu undang-undang lahir dalam bayang-bayang kepentingan politik elite, yang bertolak belakang dengan nilai-nilai dalam konstitusi, baik pada aspek prosedur pembuatan, maupun substansinya. ${ }^{14}$

Perubahan paradigma ini dalam perkembangannya tidaklah berjalan selalu mulus. Kerap kali terjadi ketegangan dalan interaksi Mahkamah Konstitusi dengan pembentuk undang-undang. Pembentuk undang-undang, selain kerap tidak melaksanakan putusan, ${ }^{15}$ juga menunjukkan sikap resisten terhadap institusi MK. Studi George Stephan Vanberg di Jerman memaparkan reaksi atas putusan Mahkamah. Menurutnya ada tiga alternatif bagi bundestag, yaitu mematuhi, menghindari, atau menentang. Vanberg menyatakan, in reacting to a decision by the court, a Bundestag majority has essentially three alternatives available: to comply, to evade, or to defy. ${ }^{16}$ Padahal, ketika pembentuk undang-undang menentang atau mengabaikan putusan Mahkamah Konstitusi, maka sulit mengharapkan legislasi sejalan dengan isi

14 Hadirnya undang-undang yang dibatalkan oleh MK baik secara materil maupun formil membuktikan bahwa terdapat undang-undang yang lahir dalam bayang-bayang kepentingan politik elite, yang bertolak belakang dengan nilai-nilai dalam konstitusi.

15 Beberapa contoh putusan Mahkamah Konstitusi yang tidak dilanjuti oleh pembentuk undang-undang adalah Putusan Nomor 98/PUU-VII/2009 (Perkara Pengujian Undang-Undang Nomor 42 Tahun 2008 tentang Pemilihan Umum Presiden dan Wakil Presiden terhadap Undang-Undang Dasar Negara Republik Indonesia Tahun 1945), khususnya mengenai larangan pengumuman hasil hitung cepat (quick count) pada masa tenang hingga waktu pencoblosan saat pemilu. Larangan dan ancaman pidana ini telah dibatalkan, namun kembali muncul dalam Pasal 449 ayat (2) dan Pasal 509 Undang-Undang Nomor 7 Tahun 2017 tentang Pemilu. Selain itu, ada pula Putusan MK No. 52/PUU-X/2012 (Perkara Pengujian UndangUndang Nomor 8 Tahun 2012 tentang Pemilihan Umum Anggota Dewan Perwakilan Rakyat, Dewan Perwakilan Daerah, dan Dewan Perwakilan Rakyat Daerah terhadap Undang-Undang Dasar Negara Republik Indonesia Tahun 1945) yang menganulir aturan mengenai ambang batas perolehan suara partai politik pesrtta pemilu namun kembali dihidupkan dalam pasal 173 ayat (3) Undang-Undang Pemilu.

16 George Stephan Vanberg, The Politics of Constitutional Review: Constitutional Court and Parliament in Germany (New York: University of Rochester, 1999), hlm. 209. 
putusan. ${ }^{17}$ Akan berpeluang suatu norma undang-undang yang telah dinyatakan inkonstitusional oleh Mahkamah diberlakukan kembali melalui legislasi setelah putusan tersebut. ${ }^{18}$

Dalam upaya perubahan menuju supremasi Konstitusi, Konstitusi (UUD NRI Tahun 1945) sesungguhnya telah memberikan kerangka susunan kehidupan bernegara untuk mencapai cita-cita dan tujuan nasional. Di dalam Konstitusi terdapat sistem hubungan dan tata kerja antar lembaga-lembaga negara sebagai pemegang kekuasaan negara, termasuk tugas, fungsi, dan wewenang masingmasing lembaga. Dalam sistem tersebut, terdapat sub-sistem yang mempunyai hubungan fungsional, sehingga hubungan tersebut menimbulkan ketergantungan. Jika salah satu sub-sistem tidak bekerja dengan baik, maka sub-sistem yang lain akan terpengaruh dan mempengaruhi keseluruhan sistem. ${ }^{19}$

17 Lihat Saldi Isra, Pergeseran Fungsi Legislasi, Menguatnya Model Legislasi Parlementer dalam Sistem Presidensial Indonesia (Jakarta: Rajawali Press, 2003), hlm. 78-79.

18 Sehubungan dengan hal ini, ada perdebatan mengenai sejauh mana pembuat undang-undang terikat dalam satu putusan tertentu apakah meliputi larangan untuk mengundangkan undang-undang yang sama dengan yang telah dibatalkan oleh Mahkamah Konstitusi, apakah sebagaimana dikemukakan Franc Testen, merujuk kepada konsep Wiederholungsverbot, terdapat larangan bagi parlemen untuk mengundangkan kembali undangundang yang telah dibatalakan oleh Mahkamah Konstitusi. Namun demikian, dalam yurisprudensi Mahkamah Konstitusi Jerman konsep Wiederholungsverbot telah ditinggalkan dalam doktrin Konstitusi modern. Mahkamah Konstitusi Jerman menganut konsep Wiederholungsverbot, baru pada tahun 1987, doktrin tersebut ditinggalkan. Mahkamah konstitusi Jeman mengatakan bahwa kekuatan mengikat putusan Mahkamah yang menyatakan kebatalan undang-undang, tidak menghalangi parlemen untuk mengesahkan undang-undang yang sama atau hampir serupa dengan undang-undang yang dibatalkan, karena kekuatan mengikat putusan Mahkamah demikian hanya mempunyai kekuatan hukum sebagai undang-undang biasa, sedangkan kekuatan legislatif semata-mata hanya terikat terhadap tertib Konstitusi, sehingga karenanya legislatir tidak dapat dihambat atau dihalangi untuk melaksanakan tanggungjawa legislatifnya menyesuaikan undang-undang dengan persyaratan dan tertib sosial yang sedang berubah. Anke Eilers, sebagaimana dikutip oleh Fajar Laksono Suroso, Potret Relasi Mahkamah Konstitusi-Legislator: Konfrontatif atau Kooperatif? (Yogyakarta: Genta Publishing, 2018), hlm. 12-13.

19 Titik Triwulan Tutik, Konstruksi Hukum Tata Negara Indonesia Pasca 
Semua Konstitusi selalu menjadikan kekuasaan sebagai pusat perhatian, karena kekuasaan itu sendiri pada intinya memang perlu diatur dan dibatasi sebagaimana mestinya. Constitutions, menurut Ivo D. Duchacek, adalah "identify the source, purposes, uses and restraints of public power" 20 (mengidentifikasi sumber-sumber, tujuan-tujuan, penggunaan-penggunaan, dan pembatasan-pembatasan kekuasaan umum). Pembatasan kekuasaan pada umumnya diangap merupakan corak umum materi Konstitusi. Oleh sebab itu pula, konstitusionalisme seperti dikemukakan oleh Friedrich adalah "an institunalised system of effevtive regularised restraints upon governmental action". ${ }^{21}$ Dalam pengertian demikian, persoalan yang dianggap terpenting dalam setiap Konstitusi adalah pengaturan mengenai pembatasan terhadap kekuasaan pemerintah. ${ }^{22}$

\section{Mahkamah Konstitusi sebagai Penafsir Konstitusi}

Pandangan-pandangan mengenai kewenangan lembaga peradilan untuk menilai cacat atau tidaknya produk legislasi atau peraturan perundang-undangan lainnya tetap saja menimbulkan perdebatan dan tanda tanya. Pertanyaan yang seringkali mengemuka pasca putusan Marshall dalam kasus Marbury Vs. Madison dalam studi hukum di Amerika adalah, Pertama, apakah memang ide uji materi itu tepat untuk dipraktikkan, dan haruskah hakim yang tidak dipilih rakyat (sebagai pemegang kedaulatan) memiliki wewenang untuk menyatakan apa yang harus dilakukan oleh lembaga perwakilan yang dipilih langsung oleh rakyat. Kedua, apakah peradilan akan lebih mudah untuk menghalangi setiap konsensus dengan prinsipprinsip kuno yang mereka anut atau untuk mencegah kelemahan politik dari kekuasaan mayoritas yang seringkali bertindak oppresif

Amandemen UUD 1945 (Jakarta: Kencana, 2011), hlm. 147.

20 Ivo D. Duchacek, "Constition and Constitutionalism", dalam Blackwell's Encyclopedia of Political Science, ed. Bogdanor dan Vernon(Oxford: Blackwell, 1987), hlm. 142.

21 C.J. Friedrich, Man and His Government (New York: McGraw-Hill, 1963), hlm. 217.

22 Lihat Padmo Wahyono, Masalah Ketatanegaraan Indonesia Dewasa ini (Jakarta: Ghalia Indonesia 1984), hlm. 10. 
(menekan). Ketiga, apakah hakim, terlindungi dengan jabatan seumur hidup (prinsip during good behavior yang dianut untuk masa jabatan hakim di Amerika) dan digambarkan secara umum berasal dari golongan terdidik, lebih mudah untuk merefleksi dan lebih mampu menghilangkan antusiasme dibandingkan dengan jalannya kewenangan legislatif. Keempat, apakah Marbury beranggapan bahwa anggota legislatif ataupun pejabat lembaga eksekutif tidak memiliki pertanggungjawaban untuk menilai konstitusionalitas dari tindakan mereka sendiri. Kelima, bisakah kita memiliki sebuah sistem pemerintahan yang dapat berjalan dengan baik tanpa adanya proses uji materi. ${ }^{23}$

Pandangan-pandangan yang mempertanyakan sekaligus mempermasalahkan kewenangan uji materi oleh lembaga peradilan hingga masih sering disampaikan. Di Indonesia sendiri, sampai dengan 2010 lalu, tidak jarang dijumpai pihak-pihak yang menggugat kewenangan Mahkamah Konstitusi untuk melakukan uji materi. Pandangan yang mempermasalahkan kewenangan uji materi tersebut dijawab oleh pakar lain dengan memberikan logika pentingnya fungsi uji oleh lembaga peradilan itu sendiri. Selain itu, praktik ketatanegaraan semakin menunjukkan bahwa uji materi oleh lembaga peradilan adalah kebutuhan yang mendesak. Hukum dalam bentuk undangundang yang disahkan oleh pemerintah dan parlemen tidaklah selamanya baik, terlebih proses pembuatannya bahkan substansinya tidak akan bisa lepas dari kepentingan politik pembuatnya. Di sisi lain, Lawrence M. Friedman dan Stewart Macaulay memaparkan bahwa independensi lembaga peradilan dari intervensi pelbagai kepentingan dan kekuasaan hanya dapat terlaksana apabila lembaga yudikatif tersebut memiliki kewenangan uji materi. Hal itu dianggap berguna bagi yudikatif dalam menjalankan hubungan dengan lembaga-lembaga yang sejajar. Friedman menjelaskan selengkapnya sebagai berikut: ${ }^{24}$

23 http: / / www.law.umkc.edu/faculty / projects / ftrials / conlaw / judicialrev. htm. diakses 28/10/2019.

24 Lawrence M. Friedman dan Stewart Macaulay (ed.), Law and the Behavioral Sciences (New York: The Bobbs-Merrill Company, Inc., 1969), hlm. 834. 
Judicial independence requires the exercise of judicial review to protect the court system against interference from states, military tribunals, plaintiffs, lawyers, and the mass media of communication, especially the press. Self restraint may be practiced by the judiciary in relation to states and localities as well as in relation to the President, Congress and administrative bodies.

Berkait kelindan dengan relasi antara uji materi dengan independensi kekuasaan kehakiman ini, menurut Friedman, pelaksanaan uji materi akan melindungi sistem peradilan dari campur-tangan atau tekanan-tekanan (misalnya politik) dari luar lembaga peradilan. Tidak dapat dipungkiri bahwa sampai hari ini independensi lembaga peradilan masih kerap mendapatkan rongrongan dari kekuasaan lainnya. Jika independensi adalah norma atau atribut penting dalam dunia peradilan maka penggunaan uji materi untuk pencapaian tersebut jelas diperlukan. Lebih lanjut, Fridmen menjelaskan: ${ }^{25}$

More importantly, it is through its exercise of judicial review that the Court can protect the judicial system from undue external pressures. Thus, structural factors would seem to make this a "pivotal" norm. If judicial independence is a pivotal role attribute, we should expect to find it, and the necessary use of judicial review included in philosophies of both Justice Jackson and Douglas.

Kewenangan uji materi suatu produk legislasi pada praktiknya mengharuskan lembaga peradilan memiliki kewenangan baru, yaitu kewenangan untuk menafsirkan Konstitusi. Tidak semua pasal dalam Konstitusi memiliki makna yang lugas dan tersurat, dan karenanya penafsiran konstitusi menjadi sesuatu yang tidak terhindarkan. Oleh karena itu sering dinyatakan, constitutional court itu adalah "the guardian of constitution and the sole interpreting of constitution". Ia disebut sebagai penjaga Konstitusi, dikarenakan kewenangan yang dimiliki dalam memutus apakah sebuah produk legislasi telah sesuai dengan Konstitusi atau tidak. Baik pada aspek substansi maupun proses pembuatannya, produk legislasi harus mengacu pada ketentuan peraturan perundang-undangan. Ia juga disebut sebagai satu-satunyalembaga yang dapat menafsirkan Konstitusi, dikarenakan kewenangan uji materi menciptakan kewenangan tersebut. Kewe-

25 Friedman dan Macaulay, Law and the Behavioral Sciences, hlm. 841. 
nangan menafsirkan itu timbul dari sebuah tafsir pula bahwa bagaimana bisa melakukan uji terhadap sebuah undang-undang agar berkesesuaian dengan Konstitusi apabila tidak diberi kewenangan memaknai dan menafsirkan Konstitusi itu sendiri. Dengan kata lain, kewenangan untuk menafsirkan ini tidaklah diamanatkan oleh Konstitusi melainkan muncul atas sebuah penafsiran.

Dalam ilmu perundang-undangan, dikenal dua istilah yang terkait dengan penafsiran hakim, yaitu judicial review dan constitutional review. Tulisan ini membedakan kedua istilah tersebut dengan alasan, pertama, constitutional review bukanlah hak tunggal dari lembaga peradilan. ${ }^{26}$ Wewenang uji konstitusional bergantung pada ketentuan Konstitusimasing-masingnegara. Ada Konstitusiyangmemberikanuji konstitusionalitas kepada sebuah Dewan Konstitusi seperti Prancis. Di Indonesia, sebelum Mahkamah Konstitusi dibentuk pada tahun 2003 lalu, pengujian Konstitusi dilakukan oleh Majelis Permusyawaratan Rakyat (MPR), sekalipun pada praktiknya hingga 1999 sama sekali tidak pernah MPR menjalankan kewenangan tersebut. Kedua, istilah judicial review (uji materi) tidak hanya bermakna pengujian undangundang terhadap UUD, melainkan dapat pula bermakna pengujian terhadap peraturan perundang-undangan di bawah undang-undang. ${ }^{27}$ Dalam konteks ini, penggunaan istilah constitutional review hanya sesuai dengan proses uji konstitusionalitas terhadap produk hukum di bawah Konstitusi. Berdasarkan argumentasi ini dapat pula digunakan istilah yang lebih tepat, sebagaimana dikemukakan Vicki C. Jackson dan Mark Tushnet, yaitu constitutional judicial review, pengujian konstitusional yang dilakukan lembaga peradilan, ${ }^{28}$ sekalipun jika digunakan istilah ini juga justru akan mempersempit kewenangan

26 Bandingkan dalam Luthfi Widagdo Eddyono, "Catatan Eksplorative Perkembangan Constitutional Review”, Jurnal Konstitusi, 2, 1 (2005). Tulisan ini merupakan resensi terhadap buku karangan Jimly Asshiddiqie, Model-Model Pengujian Konstitusional di Berbagai Negara (Jakarta: Penerbit Konstitusi Press, 2005).

27 Judicial review refers to the ultimate authority of the Supreme Court to judge whether [a] a state law or [b] a national law. Http: / / www.historyofsupremecourt.org/ history/defines / overview.htm., diakses 28/10/2019.

28 Vicki C. Jackson dan Mark Tushnet, Comparative Constitutional Law (New York: Foundation Press, 1999), hlm. 456. 
Mahkamah Konstitusi, dikarenakan tidak menutup kemungkinan ke depan kewenangan uji materi akan berada pada satu atap di bawah Mahkamah Konstitusi.

Hak untuk memberikan tafsir terhadap Konstitusi maupun produk hukum lainnya memang bukanlah kewenangan monopoli dari lembaga peradilan. ${ }^{29}$ Pemerintah dan DPR juga memiliki kewenangan tersebut dalam konteks open legal policy maupun diskresi. Namun demikian, agar penafsiran terhadap teks Konstitusi memiliki kekuatan hukum yang dapat diakui seluruh elemen negara, maka peradilan diberikan kewenangan untuk memberikan tafsir tersebut. Dengan demikian, penafsiran Konstitusi yang dimiliki oleh pembuat undang-undang dan lembaga peradilan adalah dua hal yang terpisah. Pemerintah dan parlemen menafsirkan peraturan perundang-undangan untuk menjalankan peraturan tersebut, sedangkan lembaga peradilan menafsirkan suatu peraturan untuk menguji keabsahan norma dalam peraturan tersebut.

Oleh karena penafsir utama dari sebuah produk hukum dalam konteks menilai keabsahan norma adalah hakim, maka seorang hakim dituntut untuk memiliki dua hal sekaligus. Pertama, kompetensi keilmuan agar dapat menilai keabsahan suatu norma secara luas dan mendasar. Kedua, kompetensi integritas karena seseorang yang cacat integritas tidak layak disematkan hak menafsirkan peraturan perundang-undangan pada dirinya. Carl Von Savigny, seorang pakar hukum Jerman mengajarkan tentang penafsiran sebagai rekonstruksi pikiran yang tersimpul dalam undang-undang. Menurut Savigny, penafsiran hukum bukanlah metode yang dapat digunakan semaunya melainkan harus terpusat kepada penafsiran undang-undang. ${ }^{30}$ Interpretasi atau menafsir undang-undang (wetsuitleg) menurut ajaran hukum sebenarnya adalah alat pembantu dalam memberi arti,

29 Bandingkan dengan Walter Murphy, Constitutional Interpretation as Constitutional Creation: The 1999-2000 Harry Eckstein Lecture (Irvine: University of California, 2000), hlm. 5. Paper ini juga dapat diakses melalui laman http: / / repositories.cdlib.org/csd/00-05, diakses 28/10/2019.

30 Bandingkan dengan Soedikno Mertokusumo, Penemuan Hukum: Sebuah Pengantar (Yogyakarta: Liberty, 2001), hlm. 56-57. 
maksud atau ratio terhadap suatu ketentuan undang-undang. ${ }^{31}$

Oleh karena itu, penafsiran tidaklah dapat dilakukan sembarangan dan serampangan. Seorang hakim yang kehilangan salah satu atau kedua syarat tersebut, kompetensi keilmuan dan kompetensi integritas, sesungguhnya telah kehilangan hak untuk menjadi seorang penafsir.

\section{Checks and Balances dalam Putusan Mahkamah Konstitusi}

Bagian artikel ini akan menjawab pertanyaan pokok dalam penelitian ini, yaitu korelasi antara bangunan sistem checks and balances yang dikonstruksikan dalam UUD NRI Tahun 1945 dan putusan Mahkamah Konstitusi yang kerap berisi perintah dan rekomendasi kepada pembentuk undang-undang. Dengan kata lain, ditinjau dari perspektif checks and balances, apakah Mahkamah Konstitusi dibolehkan menyampaikan mandat konstitusional berupa perintah dan rekomendasi kepada pembentuk undang-undang dalam pertimbangan hukum putusan, atau sebaliknya, apakah dengan demikian, Mahkamah Konstitusi dapat dikatakan memasuki wilayah kewenangan pembentuk undang-undang.

Sebelum sampai ke sana, penting untuk dikemukakan kembali bahwa sebagai penafsir konstitusi, Mahkamah Konstitusi pernah menyatakan dalam putusannya perihal prinsip checks and balances berdasarkan UUD NRI Tahun 1945. Menurut Mahkamah, hubungan kekuasaan dalam kerangka checks and balances antar lembaga negara didasarkan pada prinsip kekuasaan dibatasi kekuasaan (power limited by power) dan bukan kekuasaan mengawasi kekuasaan lain (power supervises other power), apalagi kekuasaan dikontrol oleh kekuasaan lain (power controls other power). Checks and balances menjaga agar suatu cabang kekuasaan pemerintahan tidak terlalu kuat kekuasaannya. ${ }^{32}$

31 John Z. Loundoe, Menemukan Hukum Melalui Tafsir dan Fakta (Jakarta: Penerbit Bina Aksara, 1985), hlm. 82.

32 Mahkamah Konstitusi Republik Indonesia, Putusan Nomor 1-2/PUUXII / 2014, Perkara Pengujian Undang-Undang Nomor 4 Tahun 2014 tentang Penetapan Peraturan Pemerintah Pengganti Undang-Undang Nomor 1 Tahun 2013 tentang Perubahan Kedua Atas Undang-Undang Nomor 24 Tahun 2003 tentang Mahkamah Konstitusi Menjadi Undang-Undang, 
Beberapa contoh putusan Mahkamah Konstitusi yang dinilai berisi perintah, larangan, mandat, atau rekomendasiterhadaplembaga pembentuk undang-undang adalah, pertama, putusan Nomor 005 / PUU-IV/2006 dalam Pengujian Undang-Undang Komisi Yudisial. ${ }^{33}$ Dalampertimbanganputusan, Mahkamahmerekomendasikankepada DPR dan Presiden untuk segera mengambil langkah penyempurnaan Undang-Undang tersebut. Bahkan, DPR dan Presiden juga dianjurkan untuk melakukan perbaikan-perbaikan yang bersifat integral. Kedua, putusan Nomor 4/PUU-VII/ 2009 dalam pengujian Undang-Undang Pemilu dan Undang-Undang Pemerintahan Daerah. ${ }^{34}$ Dalam pertimbangan hukumnya, Mahkamah mendorong agar pembentuk undangundang lebih bersungguh-sungguh untuk meninjau kembali semua peraturan perundang-undangan sepanjang yang berkaitan dengan hak pilih mantan terpidana sehingga disesuaikan dengan putusan ini.

Ketiga, putusan Mahkamah Konstitusi Nomor 97/PUUXI/2013 perihal pengujian Undang-Undang Pemerintahan Daerah. ${ }^{35}$ Dalam pertimbangannya Mahkamah menyatakan kewenangan lembaga negara yang secara limitatif ditentukan oleh UUD NRI

terhadap Undang-Undang Dasar Negara Republik Indonesia Tahun 1945, hlm. 105-106.

33 Mahkamah Konstitusi Republik Indonesia, Putusan Nomor 005/PUUIV/2006, Perkara Pengujian Undang-Undang Nomor 22 Tahun 2004 tentang Komisi Yudisial dan Pengujian Undang-Undang Nomor 4 Tahun 2004 tentang Kekuasaan Kehakiman terhadap Undang-Undang Dasar Negara Republik Indonesia Tahun 1945.

34 Mahkamah Konstitusi Republik Indonesia, Putusan Nomor 4/PUUVII/2009, Perkara Pengujian Undang-Undang Nomor 10 Tahun 2008 tentang Pemilihan Umum Anggota Dewan Perwakilan Rakyat, Dewan Perwakilan Daerah, dan Dewan Perwakilan Rakyat Daerah dan UndangUndang Nomor 12 Tahun 2008 tentang Perubahan Kedua Atas UndangUndang Nomor 32 Tahun 2004 tentang Pemerintahan Daerah terhadap Undang-Undang Dasar Negara Republik Indonesia Tahun 1945.

35 Mahkamah Konstitusi Republik Indonesia, Putusan Nomor 97/PUUXI/2013, Perkara Pengujian Undang-Undang Nomor 12 Tahun 2008 tentang Perubahan Kedua Atas Undang-Undang Nomor 32 Tahun 2004 tentang Pemerintahan Daerah dan Undang-Undang Nomor 48 Tahun 2009 tentang Kekuasaan Kehakiman terhadap Undang-Undang Dasar Negara Republik Indonesia Tahun 1945. 
Tahun 1945 tidak dapat ditambah atau dikurangi oleh undangundang maupun putusan Mahkamah karena akan mengambil peran sebagai pembentuk UUD. Keempat, putusan Nomor 012-016-019/ PUU-IV/2006 perihal pengujian Undang-Undang Pemberantasan Korupsi. ${ }^{36}$ Dalam pertimbangan hukumnya Mahkamah menyatakan pembuat undang-undang harus sesegera mungkin melakukan penyelarasan Uundang-Undang ini dengan UUD NRI Tahun 1945 dan membentuk Undang-Undang Pengadilan Tipikor. Kelima, putusan Nomor 13/PUU-VI/2008 perihal pengujian UndangUndang Anggaran Pendapatan dan Belanja Negara Tahun 2008. ${ }^{37}$ Dalam pertimbangannya Mahkamah menyatakan perlu sekali lagi mengingatkan pembentuk undang-undang untuk memenuhi kewajiban konstitusionalnya menyediakan anggaran sekurangkurangnya 20 persen bagi pendidikan, selambat-lambatnya dalam tahun anggaran 2009.

Dengan konstruksi yang dibangun dalam UUD NRI Tahun 1945, MahkamahKonstitusisebagaisalahsatupelakukekuasaankehakiman, diberi kewenangan melaksanakan ajudikasi konstitusional melalui mekanisme peradilan Konstitusi di bawah supremasi Konstitusi. Ajudikasi konstitusional dilakukan untuk menjaga konstitusi. Hal ini berarti Mahkamah Konstitusi menjaga nilai Konstitusi (constitutional values) melalui pengujian konstitusional, guna mengontrol dan memastikan bahwa tata hukum yang ada, yang terwujud dalam hierarki peraturan perundang-undangan, sesuai dengan nilai-nilai UUD NRI Tahun 1945. Alasan utama diadopsinya mekanisme peradilan konstitusional (constitutional adjudication) dalam sistem ketatanegaraan Indonesia, yang ditandai dengan dibentuknya Mahkamah

36 Mahkamah Konstitusi Republik Indonesia, Putusan Nomor 012-016-019/ PUU-IV/2006, Perkara Pengujian Undang-Undang Nomor 30 Tahun 2002 tentang Komisi Pemberantasan Tindak Pidana Korupsi terhadap UndangUndang Dasar Negara Republik Indonesia Tahun 1945.

37 Mahkamah Konstitusi Republik Indonesia, Putusan Nomor 13/PUUVI/2008, Perkara Pengujian Undang-Undang Nomor 16 Tahun 2008 tentang Perubahan Atas Undang-Undang Nomor 45 Tahun 2007 tentang Anggaran Pendapatan dan Belanja Negara Tahun Anggaran 2008 terhadap Undang-Undang Dasar Negara Republik Indonesia Tahun 1945. 
Konstitusi, adalah agar Konstitusi (in casu UUD NRI Tahun 1945) sungguh-sungguh dijalankan atau ditegakkan dalam praktik, sehingga konkordan dengan dianutnya paham negara hukum dalam UUD NRI Tahun $1945 .^{38}$

Ajudikasi konstitusional ini erat kaitannya dengan penafsiran Konstitusi. Terlebih lagi penafsiran Konstitusi yang mempunyai kekuatan mengikat adalah penafsiran yang dilakukan oleh pengadilan (judicial interpretation). Kewenangan otoritatif pengadilan menafsirkan Konstitusi dapat dijumpai dalam kata-kata John Marshal pada putusannya dalam kasus Marburry v. Madison: ${ }^{39}$

It is emphatically the province and duty of the judicial departement to say what the law is. Those who apply the rule to particular cases must of necessity expound and interpret the rule. If two law conflict with each other, the courts must decide on the operation the each. So if a law be in opposition to the constitution; if both the law and constitution apply to a particular case, so that the court must either decide that case conformably to a law, disregarding the law, the court must determine which of these conflicting rules governs the case. This is very essence of judicial duty.

Pernyataan Marshall dalam putusan tersebut bukan hanya dianggap sebagai pemberi landasan pembenar bagi peradilan untuk menjadi penafsir Konstitusi, melainkan juga menjadi preseden untuk memandang kekuasaan peradilan yang memberi landasan bagi Mahkamah Agung (in casu Mahkamah Agung Amerika Serikat) sebagai arbiter masalah-masalah Konstitusi (arbiter of constitutional questions)..$^{40}$

Bertolak dari argumentasi teoretis yang sudah dikemukakan, maka dalam fungsi sebagai penafsir Konstitusi, Mahkamah Konstitusi dapat dikatakan menjadi lembaga yang paling berwenang menetapkan apa yang dikehendaki oleh Konstitusi, baik pada masa sekarang maupun mendatang. Salah satu premis dasar dari Konstitusi

38 Jimly Ashiddiqie dan Ahmad Syahrizal, Peradilan Konstitusi di Sepuluh Negara (Jakarta: Sinar Grafika, 2012), hlm. x.

39 Dalam Robert G. McCloskey, The American Supreme Court, ed. Sanford Levinson (Chicago dan London: The University of Chicago Press, 2005), hlm. 50-53. Lihat pula Suroso, Potret Relasi Mahkamah Konstitusi-Legislator, hlm. 241.

40 Suroso, Potret Relasi Mahkamah Konstitusi-Legislator, hlm. 243. 
tertulis, di mana UUD NRI Tahun 1945 termasuk di dalamnya, adalah kapasitasnya untuk menjangkau masa depan, dalam arti kemampuannya untuk beradaptasi dengan persoalan-persoalan yang muncul di masa mendatang. Wilayah jangkauan Konstitusi tersebut serta merta berada dalam kewenangan Mahkamah Konstitusi.

Dengan pemahaman demikian, mandat konstitusionalitas Mahkamah Konstitusi wajib diposisikan sebagai penafsir Konstitusi yang mengikat dan harus diikuti, in casu oleh pembentuk undang-undang. Dengan demikian, makin jelas, mandat konstitusional Mahkamah Konstitusi kepada pembentuk undang-undang yang dilakukan dalam konteks penafsiran Konstitusi harus dipahami sebagai tindakan yang berada dalam kerangka checks and balances sebagaimana dimaksud dalam UUD NRI Tahun 1945.

Dalam kerangka checks and balances antar lembaga negara menurut UUD NRI Tahun 1945 yang pada pokoknya didasarkan pada prinsip kekuasaan dibatasi dengan kekuasaan dan bukan kekuasaan mengawasi apalagi mengontrol kekuasaan lain, maka penafsiran Konstitusi oleh Mahkamah Konstitusi yang dituangkan dalam putusan, yang di dalamnya terdapat pertimbangan hukum dengan mandat konstitusional, merupakan pembatasan bagi pembentuk undangundang. Ini artinya, keleluasaan pembentuk undang-undang dalam menjalankan fungsi legislasi dibatasi oleh adanya tafsir Konstitusi yang dilakukan oleh Mahkamah Konstitusi. ${ }^{41}$

Ada retorika yang sangat terkenal dikemukakan oleh hakim Charles Evans Hughes, "We are under a constitution, but the constitution is what the judge say it is". ${ }^{42}$ Dengan demikian, apa yang disebut konstitusional bukan lain adalah apa yang dikatakan hakim. Batasan konstitusional, dengan begitu merupakan konsekuensi dari pelaksanaan fungsi selaku penafsir Konstitusi yang melekat pada kewenangan Mahkamah Konstitusi dalam menguji undang-undang, sebagaimana diamanatkan UUD NRI Tahun 1945. Tegasnya, sebagai wujud dari prinsip kekuasaan dibatasi kekuasaan (power limited by power), kewenangan pembentuk undang-undang menafsirkan

41 Suroso, Potret Relasi Mahkamah Konstitusi-Legislator, hlm. 244.

42 Suroso, Potret Relasi Mahkamah Konstitusi-Legislator, hlm. 244. 
Konstitusi melalui legislasi dibatasi oleh penafsiran Konstitusi yang dilakukan Mahkamah Konstitusi melalui putusannya. Demikianlah prinsip supremasi Konstitusi dalam konteks negara hukum yang menempatkan Konstitusi sebagai hukum tertinggi dan Mahkamah Konstitusi diberi kewenangan konstitusional sebagai pengawalnya.

Oleh karena itu, pertanyaan apakah Mahkamah Konstitusi dapat dikatakan menyerobot kewenangan DPR dan Presiden selaku pembentuk undang-undang mendapatkan jawaban tidak sama sekali. Sebab, mandat konstitusional dalam pertimbangan putusan harus dipahami sebagai sesuatu yang inherent dalam pelaksanaan fungsi Mahkamah Konstitusi sebagai penafsir Konstitusi yang acap kali tidak terhindarkan mengandung elemen judicial activism. ${ }^{43}$ Ini artinya, penafsiran Konstitusi atas norma undang-undang yang diuji kerap kali terkandung elemen judicial activism. Dengan perkataan lain, elemen judicial activism dengan sendirinya melekat dalam diri Mahkamah Konstitusi sebagai penafsir Konstitusi, terutama dalam upayanya mencari jawaban atas pertanyaan apa sesungguhnya fungsi yang diberikan kepadanya oleh UUD NRI Tahun 1945 dalam kaitan dengan tujuan-tujuan yang hendak dicapai oleh UUD.

Dengan demikian, penting untuk ditegaskan kembali, keberadaan mandat konstitusional dalam pertimbangan hukum putusan Mahkamah Konstitusi bukanlah wujud intervensi ke dalam area kewenangan pembentuk undang-undang yang dipandang melampaui prinsip batasan checks and belances. Substansi pertimbangan hukum demikian sama sekali bukan untuk mendikte DPR dan Presiden dalam menjalankan fungsi legislasi. Dalam kondisi demikian, sebagaimana disebut Fajar Laksono Suroso, istilah ikut campur atau melampaui batas tidaklah tepat. Akan lebih tepat dikatakan, dengan fungsi sebagai penafsir Konstitusi, Mahkamah Konstitusi melalui putusannya mendahului pembentuk undang-undang dalam menafsirkan Konstitusi, karena memang demikian amanat Konstitusi. Tafsir Konstitusi tersebut diwujudkan oleh Mahkamah

43 Mengenai kekuatan hukum bagian pertimbangan dalam Putusan MK, telah diteliti dengan sangat lengkap oleh Fajar Laksono Suroso dalam Penelitian Disertasinya di Universitas Brawijaya Tahun 2018. 
Konstitusi ke dalam mandat kepada pembentuk undang-undang untuk memperbaiki cacat konstitusional dalam suatu undangundang. Hal ini sebagaimana dikatakan Howard Ball, ${ }^{44}$

Undang-undang sebagai produk proses politik yang diuji oleh Mahkamah Konstitusi sebagai kewenangan yang diterapkan untuk mencegah proses kebijakan yang bisa menyimpang jauh dari mandat Konstitusi, sehingga lembaga yang tidak demokratis seperti Mahkamah Konstitusi sesungguhnya membantu dan mendukung democratic majoritarianisme dengan bersikeras mendesak agar lembaga-lembaga politik bertindak dalam kerangka kekuasaan yang disebut dalam konstitusi, agar ketika merumuskan undang-undang memperhitungkan batas-batas konstitusional yang ada.

Bertolak dari pendapat tersebut, maka batasan-batasan konstitusional itulah yang disampaikan Mahkamah Konstitusi melalui tafsir konstitusional yang dituangkan dalam putusan. Dengan dasar itulah pembentuk undang-undang berkewajiban untuk tunduk pada tafsiran Konstitusi dimaksud. Prinsip checks and balances di antara kekuasaan negara untuk menciptakan keseimbangan dan koordinasi yang sederajat menuntut kesetiaan terhadap prinsip Konstitusi yang dianut. Jika saja pembentuk undang-undang diperbolehkan mengabaikan atau mengingkari putusan Mahkamah Konstitusi yang berisi mandat, perintah, rekomendasi, atau larangan, maka hal demikian dapat menjurus kepada kondisi: 1) konstitusi tidak kunjung dapat ditegakkan; 2) eksistensi Mahkamah Konstitusi tidak berdayaguna dalam menata sistem hukum dan ketatanegaraan; 3) putusan Mahkamah Konstitusi kehilangan kewibawaannya; 4) tidak dapat dibendungnya undang-undang yang dibentuk pasca putusan Mahkamah Konstitusi yang berpotensi mengandung problem konstitusionalitas kembali. ${ }^{45}$

Bahkan, dalam tataran tertentu, pengabaian terhadap putusan Mahkamah Konstitusi dapat menjurus pada terjadinya krisis Konstitusi, yakni dengan adanya permohonan pengujian undang-undang ke Mahkamah Konstitusi, dan pembentuk undang-undang mengabaikan

44 Dikutip dari Suroso, Potret Relasi Mahkamah Konstitusi-Legislator, hlm. 245. 45 Suroso, Potret Relasi Mahkamah Konstitusi-Legislator, hlm. 246. 
putusan tersebut. ${ }^{46}$ Undang-undang yang dibuat lagi itu diuji kembali, dan kembali pula dibatalkan oleh Mahkamah Konstitusi, dan seterusnya, terjadi keberulangan. Apabila proses semacam ini berlansung, maka meminjam istilah Maruarar Siahaan, akan tercipta sebuah lingkaran checks and balances yang tidak berujung. ${ }^{47}$

\section{E. Kesimpulan}

Artikel ini menyimpulkan, mekanisme checks and balances yang diatur dalam UUD NRI Tahun 1945 diwujudkan dengan prinsip kekuasaan dibatasi oleh kekuasaan (power limited by power). Oleh karena itu, kewenangan uji materi oleh Mahkamah Konstitusi yang memasuki area kewenangan pembentuk undang-undang tidaklah berarti melampaui prinsip batasan checks and balances, sebab kewenangan pembentuk undang-undang untuk menafsirkan Konstitusi melalui legislasi dibatasi oleh penafsiran Konstitusi yang dilakukan Mahkamah melalui putusannya. Kewenangan dan putusan uji materi oleh Mahkamah Konstitusi justru menegaskan wujud dari prinsip kekuasaan dibatasi kekuasaan dan meneguhkan supremasi Konstitusi. Hal ini membuktikan bahwa putusan uji materi oleh Mahkamah Konstitusi memiliki relevansi terhadap sistem checks and

46 Analisis Bisariyadi menarik dalam kaitannya dengan kemungkinan pengabaian atau perlawan pembentuk undang-undang terhadap putusan Mahkamah Konstitusi. Menurutnya, hal itu karena Mahkamah Konstitusi dalam menguji konstitusionalitas suatu undang-undang memang dapat mengambil sikap secara aktif atau memilih menahan diri. Tapi, karena adanya perlawanan dari pembentuk undang-undang dalam bentuk mengabaikan putusan, memaksa Mahkamah Konstitusi untuk menggunakan strategi menahan-diri untuk memeriksa kebijakan yang masuk dalam ranah kewenangan diskresi dari pembentuk undang-undang, yang biasanya disebut dengan "kebijakan hukum terbuka". Pilihan ini merupakan langkah kompromis agar mengurangi konflik ketegangan politik antar lembaga negara sekaligus tetap melindungi hak-hak warga negara. Bisariyadi, "Yudisialisasi Politik dan Sikap Menahan Diri: Peran Mahkamah Konstitusi dalam Menguji Undang-Undang", Jurnal Konstitusi, 12, 3 (2015), hlm. 473.

47 Lihat Maruarar Siahaan, "Implementasi Putusan Mahkamah Konstitusi, Studi tentang Mekanisme Checks and Balances di Indonesia" (disertasi, Universitas Diponegoro, Semarang, 2010). 
balances dalam pembentukan undang-undang.

\section{Daftar Pustaka}

\section{Artikel/Buku/ Majalah}

Asshiddiqie, Jimly. Konstitusi dan Konstitusionalisme Indonesia. Jakarta: Sinar Grafika, 2010.

Ashiddiqie, Jimly. Model-Model Pengujian Konstitusional di Berbagai Negara. Jakarta: Penerbit Konstitusi Press, 2005.

Ashiddiqie, Jimly dan Ahmad Syahrizal. Peradilan Konstitusi di Sepuluh Negara. Jakarta: Sinar Grafika, 2012.

Bisariyadi. "Yudisialisasi Politik dan Sikap Menahan Diri: Peran Mahkamah Konstitusi dalam Menguji Undang-Undang”. Jurnal Konstitusi, 12, 3 (2015): 473-502. DOI: 10.31078/jk1233.

Chandranegara, Ibnu Sina. "Penuangan Checks and Balances ke dalam Konstitusi”. Jurnal Konstitusi, 13, 3 (2016): 552-574. DOI: $10.31078 / \mathrm{jk} 1334$.

Duchacek, Ivo D. "Constition and Constitutionalism". Dalam Blackwell's Encyclopedia of Political Science, diedit oleh Bogdanor dan Vernon. Oxford: Blackwell, 1987.

Eddyono, Luthfi Widagdo. "Catatan Eksplorative Perkembangan

Constitutional Review”. Jurnal Konstitusi, 2, 1 (2005).

Friedman, Lawrence M. dan Stewart Macaulay (ed.). Law and the Behavioral Sciences. New York, USA: The Bobbs-Merrill Company, Inc., 1969.

Friedrich, C.J. Man and His Government. New York: McGraw-Hill, 1963.

Gaffar, Afan. Politik Indonesia: Transisi Menuju Demokrasi. Yogyakarta:

Pustaka Pelajar, 2006.

Http: / / www.law.umkc.edu / faculty / projects / ftrials / conlaw / judicialrev.htm. Diakses 28/10/2019.

Http: / / www.historyofsupremecourt.org/history/defines / overview.htm. Diakses 28/10/2019.

Isra, Saldi. Pergeseran Fungsi Legislasi, Menguatnya Model Legislasi Parlementer dalam Sistem Presidensial Indonesia. Jakarta: Rajawali 
Press, 2003.

Jackson, Vicki C. dan Mark Tushnet. Comparative Constitutional Law.

New York: Foundation Press, 1999.

Kutaris, Gunars. "Authority of the Constitutional Court as the

Preconditions of Execution of the Decisions". Makalah

Konferensi "Execution of the Decisons of Constitutional

Court: A Cornerstone of the Process of Implementation of

Constitutional Justice" on The Occasion of the 10th Anniversary

of the Constitutional Court of Azerbaijan, Baku, Azerbaijan, 14-15 Juli 2008.

Loundoe, John Z. Menemukan Hukum Melalui Tafsir dan Fakta. Jakarta: Bina Aksara, 1985.

Mahfud MD, Moh. Demokrasi dan Konstitusi di Indonesia: Studi tentang

Interaksi Politik dan Kehidupan Ketatanegaraan. Jakarta: Rineka Cipta, 2000.

Manan, Bagir. Membedah UUD 1945. Malang: Universitas Brawijaya Press, 2012.

McCloskey, Robert G. The American Supreme Court, diedit oleh Sanford

Levinson. Chicago and London: The University of Chicago Press, 2005.

Mertokusumo, Soedikno. Penemuan Hukum, Sebuah Pengantar. Yogyakarta: Penerbit Liberty, 2001.

Murphy, Walter. Constitutional Interpretation as Constitutional Creation:

The 1999-2000 Harry Eckstein Lecture. Irvine: University of California, 2000.

Palguna, I Dewa Gede. "Pengaduan Konstitusional: Upaya Hukum terhadap Pelanggaran Hak-Hak Konstitusional Warga Negara (Studi Kewenangan Mahkamah Konstitusi Indonesia dalam Perspektif Perbandingan)”. Disertasi, Universitas Indonesia, Jakarta, 2011.

Rahardjo, Satjipto. "Sisi Lain Mahkamah Konstitusi". Kompas, $5 / 1 / 2009$.

Siahaan, Maruarar. "Implementasi Putusan Mahkamah Konstitusi,

Studi tentang Mekanisme Checks and Balances di Indonesia”. Disertasi, Universitas Diponegoro, Semarang, 2010. 
Suroso, Fajar Laksono. Potret Relasi Mahkamah Konstitusi-Legislator: Konfrontatif atau Kooperatif?. Yogyakarta: Genta Publishing, 2018.

Sweet, Alec Stone. "The Politics of Constitutional Review in France and Europe". International Journal of Constitutional Law, 5, 1 (2007): 69-92. DOI: $10.1093 / \mathrm{icon} / \mathrm{mol} 041$.

Tutik, Titik Triwulan. Konstruksi Hukum Tata Negara Indonesia Pasca Amandemen UUD 1945. Jakarta: Kencana, 2011.

Vanberg, George Stephan. The Politics of Constitutional Review: Constitutional Court and Parliament in Germany. New York: University of Rochester, 1999.

Wahyono, Padmo. Masalah Ketatanegaraan Indonesia Dewasa ini. Jakarta: Ghalia Indonesia 1984.

\section{Peraturan dan Putusan Hukum}

Republik Indonesia. Undang-Undang Dasar Negara Republik Indonesia Tahun 1945.

Republik Indonesia, Mahkamah Konstitusi. Putusan Nomor 005 / PUU-IV/2006, Perkara Pengujian Undang-Undang Nomor 22 Tahun 2004 tentang Komisi Yudisial dan Pengujian UndangUndang Nomor 4 Tahun 2004 tentang Kekuasaan Kehakiman terhadap Undang-Undang Dasar Negara Republik Indonesia Tahun 1945.

Republik Indonesia, Mahkamah Konstitusi. Putusan Nomor 012-016019/PUU-IV/2006, Perkara Pengujian Undang-Undang Nomor 30 Tahun 2002 tentang Komisi Pemberantasan Tindak Pidana Korupsi terhadap Undang-Undang Dasar Negara Republik Indonesia Tahun 1945.

Republik Indonesia, Mahkamah Konstitusi. Putusan Nomor 13/ PUU-VI/2008, Perkara Pengujian Undang-Undang Nomor 16 Tahun 2008 tentang Perubahan Atas Undang-Undang Nomor 45 Tahun 2007 tentang Anggaran Pendapatan dan Belanja Negara Tahun Anggaran 2008 terhadap Undang-Undang Dasar Negara Republik Indonesia Tahun 1945.

Republik Indonesia, Mahkamah Konstitusi. Putusan Nomor 4/ PUU- 
VII/2009, Perkara Pengujian Undang-Undang Nomor 10 Tahun 2008 tentang Pemilihan Umum Anggota Dewan Perwakilan Rakyat, Dewan Perwakilan Daerah, dan Dewan Perwakilan Rakyat Daerah dan Undang-Undang Nomor 12 Tahun 2008 tentang Perubahan Kedua Atas Undang-Undang Nomor 32 Tahun 2004 tentang Pemerintahan Daerah terhadap UndangUndang Dasar Negara Republik Indonesia Tahun 1945.

Republik Indonesia, Mahkamah Konstitusi. Putusan Nomor 98/ PUU-VII/2009, Perkara Pengujian Undang-Undang Nomor 42 Tahun 2008 tentang Pemilihan Umum Presiden dan Wakil Presiden terhadap Undang-Undang Dasar Negara Republik Indonesia Tahun 1945.

Republik Indonesia, Mahkamah Konstitusi. Putusan Nomor 52/ PUU-X/2012, Perkara Pengujian Undang-Undang Nomor

8 Tahun 2012 tentang Pemilihan Umum Anggota Dewan Perwakilan Rakyat, Dewan Perwakilan Daerah, dan Dewan Perwakilan Rakyat Daerah terhadap Undang-Undang Dasar Negara Republik Indonesia Tahun 1945.

Republik Indonesia, Mahkamah Konstitusi. Putusan Nomor 97/ PUU-XI/2013, Perkara Pengujian Undang-Undang Nomor 12 Tahun 2008 tentang Perubahan Kedua Atas Undang-Undang Nomor 32 Tahun 2004 tentang Pemerintahan Daerah dan Undang-Undang Nomor 48 Tahun 2009 tentang Kekuasaan Kehakiman terhadap Undang-Undang Dasar Negara Republik Indonesia Tahun 1945.

Republik Indonesia, Mahkamah Konstitusi. Putusan Nomor 1-2/ PUU-XII/2014, Perkara Pengujian Undang-Undang Nomor 4 Tahun 2014 tentang Penetapan Peraturan Pemerintah Pengganti Undang-Undang Nomor 1 Tahun 2013 tentang Perubahan Kedua Atas Undang-Undang Nomor 24 Tahun 2003 tentang Mahkamah Konstitusi Menjadi Undang-Undang, terhadap Undang-Undang Dasar Negara Republik Indonesia Tahun 1945. 